\title{
Development of a Garden-Based Curriculum Content Model for Indigenous Primary School Students
}

\author{
Siti Farhah A. Aziz ${ }^{1}$, Saedah Siraj ${ }^{1}$, Zaharah Hussin ${ }^{1}$, Nurul Ain Norman ${ }^{1}$, Nur Izzah Norman ${ }^{2}$ \\ ${ }^{1}$ Faculty of Education, University of Malaya, Kuala Lumpur, Malaysia \\ ${ }^{2}$ Faculty of Islamic Civilization, University of Technology Malaysia, Johore, Malaysia
}

Email address:

saedah@um.edu.my (S. Siraj)

\section{To cite this article:}

Siti Farhah A. Aziz, Saedah Siraj, Zaharah Hussin, Nurul Ain Norman, Nur Izzah Norman. Development of a Garden-Based Curriculum Content Model for Indigenous Primary School Students. Science Journal of Business and Management. Vol. 5, No. 5, 2017 , pp. 181-188. doi: $10.11648 /$ j.sjbm.20170505.11

Received: June 12, 2017; Accepted: August 10, 2017; Published: September 4, 2017

\begin{abstract}
The purpose of this paper is to report the finding on the development of Content Model of a Garden Based Curriculum on Nutritious Fruits and Vegetables for Indigenous Primary Schools. Data collection was conducted using Interpretive Structural Modelling (ISM) method to develop the model and implementing Nominal Group Technique (NGT) involving experts from various related disciplines including indigenous research, indigenous nutritional research, curriculum design, agriculture and activist from Semai ethnic for adding and dropping the elements that are presented before voting was conducted. NGT was carried out as an efficient technique for generating ideas in groups and for clarifying the generated ideas prior to the voting procedure by featured experts in ISM. Findings indicate that development of content model of a garden based curriculum on nutritious fruits and vegetables that comprises four (4) content elements. Apart from the development of content model, the development of curriculum objective model, teaching and learning methods model, evaluation and assessment model are enabled to be used as a guideline in developing modules and teaching and learning program to improve nutritious fruits and vegetables consumption for Semai Indigenous children.
\end{abstract}

Keywords: Content Model, Interpretive Structural Modeling (ISM), Nutritious, Garden Based Curriculum, Indigenous

\section{Introduction}

The education system in Malaysia has undergone various transformations aimed at ensuring the system achieves Quality Education. According to Marzuki, Mapjabil and Zainol [1], The Ministry of Education Malaysia policy expressed in the Malaysia Education Blueprint (PIPP) launched in 2012 is aimed to minimize the gap between location, socioeconomy and student ability. Although continued efforts have been made by government to narrow the gap between rural and urban education and to raise the participation of school enrolment among the population, to reduce the absenteeism and dropout rate in the Orang Asli (indigenous) population specifically in Malaysia still concern many parties [2].

The indigenous community in Malaysia has never been marginalized by the government in fulfilling the national vision. Hence, various efforts have been made by diverse government agencies including the Ministry of Education and Jabatan Hal Ehwal Orang Asli Malaysia itself [3]. Several studies have been carried out to identify the contributing factors to academic achievement among the Orang Asli community including the aconomic factor, geography, family, and individual personality [4-8], societal factor [7] and also nutrition factor [9-11].

The dietary factor among the Orang Asli children is also a key factor in the achievement of Orang Asli children; this is because a good and healthy diet will influence the cognitive development and thinking ability [12-14]. Aspects in the dietary factor can disturb cognitivedevelopment of indigenous children. According to Haslinah [8], adequate and nutritious diet direct toward good nutrition and health status for proper cognitivedevelopment in children. According to the study by Carroll [15], in children's dietary factors, some sub factors contribute to children's cognitive development including taking breakfast, consumption of sweetened drinks, intake of fruits and vegetables and also quality diet. In other 
studies, it was found that developing curricula for encouraging intake of nutritious fruits and vegetables through school gardens is important; this is because the garden based curriculum itself is an intervention program for promoting use of agricultural garden that is optimal for imparting much learning experience giving many positive effects on the attitude and behavior of children toward nutritious food, environmental knowledge, social interaction and at the same time shapes a good intellectual culture among children [1619].

This article analyzes the development of a curriculum content model based on garden of nutritious fruits and vegetables for indigenous primary schools based on the level of education of indigenous children in mainstream education. Apart from the curriculum objectives, the teaching and learning approach and curriculum evaluation and measurement, the emphasis on curriculum content is an important part of shaping the new curriculum. This is because curriculum content must be designed with practical knowledge and practical training in particular to be suitable for students so that they know how to produce and access nutritious food, enhance their behavior in consuming nutritious food, improve their nutritional status and prevent chronic diseasesby consuming better food [20]. Hence the development of a curriculum content model based on nutritious garden fruits and vegetables can help in enhancing behavior in consuming nutritious fruits and vegetables among indigenous primary school children.

\section{Limitation of the Study}

A curriculum content model based on constructed garden of nutritious fruits and vegetables is a curriculum designed specially for indigenous children in Malaysia. The gardenbased curriculum is used to focus on teaching and learning involving gardens based on nutritious fruits and vegetables to help raise the intake of nutritious food such as fruits and vegetables among the indigenous children. The research context used is among the indigenous children from the Semai community from all over Perak state. In this study, the scope of research is on developing a curriculum content model where the curriculum content elements have been developed by a team of experts through applying Interpretive Structural Modeling (ISM) applications. The focus of this research involves 11 experts selected though purposive sampling consisting of experts in indigenous studies, experts in indigenous diet, experts in curriculum development and also experts in the Semai indigenous community.

\section{Statement of the Problem}

The problem of academic achievement and failure among schoolchildren in Malaysia is a universal problem in the context of the Malaysian population today. It has made many parties playing a role in child education urgently aspire to determine that the academic achievement can ensure their future [abu talib]. Nevertheless in the Malaysian context, there still exist a minority left behind in education even though various initiatives have been implemented by the Ministry of Education Malaysia to bridge the gap in education and reduce the dropout rate among the indigenous children in Malaysia.

Among the programs implemented are development of an indigfenous curriculum such as the Kurikulum bersepadu Orang Asli / Penan or Orang Asli/Penan integrated curriculum [21-23], Program Sekolah Model Khas Komprehensif K9 [26-27], Kelas Dewasa Ibu Bapa Murid Orang Asli and Peribumi KEDAP [21] [24]. Although the gap in achievement still exists between mainstream children and Orang Asli children [25-28].

In essence, Orang Asli students are absent from school and other school academic programs because they prioritize festivals and, fruit harvesting seasons over school attendance [4]. Their frequent absence from school means that the indigenous children are lagging behind in their studies in comparison with other students. According to Mohamad Johdi Salleh and Abdul Razak [29] in their study on Orang Asli, the Orang Asli students are easily bored and fed up with teaching and learnbing activities in school. The easily bored feeling and feeling fed up with learning leads to high abseentism rate of indigenous people in schools. Studies have been done on the relationship between balanmced diet and academic achievement of children as well as their cognitive development. Studies reported that a diet with proper nutrients is the key to childhood development in Malaysia [30]. Many studies have also identified that lack of nutrients is a very serious problem among the indigenous people; Grantham and Ani [31] as well proved that the main effect of lack of nutrition from fruits and vegetables consumption among children contributes to low IQ level; furthermore, damage to cognitive function and motor development may lead to behavioral problems, reduced attention for learning, weakness, passiveness and reduced competitiveness.

A study by Rosnon [32] also stated that the government has failed to focus on the created content, pedagogy, curriculum and the teaching and learning process more focused on ensuring equitability among the indigenous people and the mainstream community. Rosnan added that for the Orang asli community, their rights must be clarified in the educational system through needs analysis and appropriate model of education so that they are not marginalized from the existing education system. Hence, in efforts to achieve the objectives, the authorities need to develop a program by selecting appropriate content and adapting the curriculum to fulfil the indigenous students' learning needs, interests and knowledge first [33].

Hence the development of a content module on garden based curriculum on nutritious fruits and vegetables was implemented to fulfil the educational needs of the indigenous Semai community especially because developing content of the curriculum is critical in devising a curriculum. In the context of education in Malaysia there is still a gap in developing a model of curriculum content based on garden fruits and vegetables specially for indigenous primary 
schools besides developing a model of homeschooling for the indigenous people (Mohd Nazri, 2014), curriculum model based on intellectualism of herbal medicine [34] and pedagogical module for the Temuan Orang Asli tribe [35].

\section{Literature Review}

\subsection{Program Elements of Curriculum Based on Garden of Nutritious Fruits and Vegetables}

The effect of interventions by curriculum on planting and consumption of nutritious fruits and vegetables on children's learning have received positive feedback among students and teachers in schools involved in applying this type of hands on learning. This was proven by past studies where the programs implemented involving intake of fruits and vegetables had a great impact on children especially in terms of knowledge about nutritious food [36-41]. Changes in the students and teachers called program outcome will not occur unless changes occur in the environment in the context of learning are carried out [42]. The garden-based education program based inculcated in nutrition education interventions can have a greater effect on the learning environment.

Activities such as planning, planting, harvesting and also consuming food planted by oneself in a progressive way can change the environment of the education curriculum by fostering involvement between children and teachers. In this way, children will naturally stimulate their thinking such that what is learned as theory in the classroom can then be applied in the real world learning context [43]. Program elements inculcated in the learning program based on nutritious plants in an elementary school in Oklahoma [44] was made as one of the approaches for involving children actively in nutritious food consumption, hands on and also the preparation of food or materials planted by the children themselves.

In the context of this study, the garden based curriculum on nutritious fruits and vegetables has focused not only on the need for nutrition from fruits and vegetables but it also took into account skill building as well as behavior toward preparation of balanced food, skills in the aspect of agriculture to increase ability and self capability in social interaction in the school community. Studies on the effectiveness prove that the curriculum program involving nutrition education and nutritional agriculture among children and elements through school gardens can help in enhancing consumption of fruits and vegetables [45-49].

\subsection{Overseas Example of Interventionof Garden Based Fruits and Vegetables Curriculum}

Got veggies? Garden-Based Nutrition Education Curriculum [50]. Got veggies? Program is a garden based educational nutritional curriculum developed with the aim of enhancing consumption of nutritious food and vegetables among children. This curriculum was developed specially for pupils in Grade 2 and Grade 3 dan had lesson plans aligned with the Wisconsin Model Academic Standard. The learning activities for this curriculumare are appropriate for elementary school pupils. The garden based education curriculum encompasses garden based activities, preparing recipes and cooking for eating in the garden itself. This curriculum provides an ideal strategy for educating and encouraging interest in consuming fresh fruits and vegetables. It is a comprehensive program for integrating nutritious food and also gardening skills in school.

\section{Farm to School}

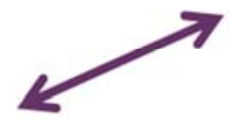

Nutrition Education

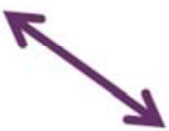

\section{School Gardens}

Figure 1. Concept of integration in nutrition education and school garden.

\subsection{Applying ISM in the Educational Context}

Several local studies have proven that application of ISM specifically in education is a new transformation in the field. Among the studies using ISM applications is a study by Mohd Nazri Abdul Rahman, Norlidah Alias, dan Saedah Siraj [51] in designing a measurement and evaluation structure for text books. Besides that, ISM was also the methodology used in publishing secondary school texts in Malaysia. In other studies, Abdullah, Siraj, Asra, dan Hussin [52] used ISM application in developing an implementation model of m-learning for English Language communication skills has also played a part in applying ISM through development of implementation models of activity-based mlearning. Sahney, Banwet, dan Karunes [53] also used ISM to identify the characteristics of a system to fulfil the customer needs of learners as external customers.

\section{Objectives}

This study aimed at developing a curriculum content model based on garden of nutritious fruits and vegetables for indigenous primary school students. Based on the research objctives, the research questions are as follows:

a) What are the curriculum content elements of the garden based curriculum on nutritious fruits and vegetables for indigenous primary school children as suggested by consensus of experts?

b) What is the shape of the curriculum content model of garden based nutritious fruits and vegetables for 
indigenous primary school children according to consensus of experts?

\section{Methodology}

In developing a curriculum content model based on garden of nutritious fruits and vegetables, using a ISM software is one basic idea to apply practical experience and expert knowledge for breaking down a complex system into several subsystems and at the same time building a hierarchical structural model [54-55]. In the context of this study ISM is used to help the panel of experts achieve consensus in concluding the relationship between elements of the curriculum content based on nutritious fruits and vegetables presented in designing a model structure. The following are the main stages in the ISM procedure. These stages are the basis for developing a model of garden based curriculum on nutritious fruits and vegetables for indigenous primary schools.

1). Identify the issues to be investigated

This stage is aimed at identifying the issues or elements to be explored using ISM. In the context of this study, the researcher has identified several content elements as issues that need to be structured by experts in order to know the relationship between the elements concerned.

2). Deciding on the type of ISM to apply

This is a very important stage for determining the shape of elements generated. This includes the relational phrase and contextual phrase in the ISM. The constructed relational phrase must be discussed by the expert panel. The discussion will be carried out in stage 4 .

3). Selecting the participants and facilitator

For this stage, the panel of experts or participants in the ISM session must be considered. Clearly in this stage it is important that participants have knowledge realted to the issues to be discussed. Based on Saedah and Abdullah [52], individuals identified as experts for this stuidy should have the following characteristics:

a. Individuals who have the training, knowledge and experience whether in agriculture, nutrition, curriculum development and also individuals who have experience in studying Orang Asli;

b. The professional group having the experience of working as teachers or educational technology officers in their respective schools or departments;

c. Individuals who are willing to take part in the workshop together to produce an ISM model with other experts.

4). Generating the element determined

In this stage, the process of producing ideas is one way for the panel itself to deploy a team to discuss elements to be structured. Studies by Janes [56] have clarified that the Nominal Group Technique (NGT) is a process found very suitable in collaboration with the ISM process. In the context of this study, NGT was carried out involving 11 experts associated with structuring the relationship among elements.

5). Complete the matrix for interactions among elements

At this stage the ISM software can be used. The set of elements to be structured is input into the computer and the expert panel has been asked to answer several questions being presented by the computer in the form of connection phrase and contextual phrase as stated in stage 2 .

At this stage also, the ISM software itself can complete the process of mathematical calculation including the Structural Self-Interaction Matrix (SSIM) and also the Initial Reachibilty Matrix for the ISM software user. Mathematical calculations for this matrix are hidden behind the sofytware technology used. Mathematical calculation of the matrix can be done manually if the user does not use ISM software.

6). Reveal the ISM

When all the questions have been answered, and the reachibility matrix has been constructed, the computer can extract the various stages of the digraph from the matrix. The computer printout of the digraph produced in the context of this study will be discussed.

7). Discuss the structure and amend it if necessary

At this stage, the facilitator or team members must play their part in discussing the ISM. This is aimed at explaining the structure to participantsso that they clearly understand how to interpret and allow them to state their opinion on it. In the context of this study, the researcher presents and interprets to the expert panel and the panel agreed to the proposed structure without any amendments.

\section{Analysis of Findings}

Constructing the elements of the garden based curriculum on nutritious fruits and vegetables was done through the ISM procedure [56].

1). In the first stage of the ISM, the researcher had identified several elements of the curriculum content as issues that needed structuring. A total of 4 elements were derived resulting from interpreting the literature review and the needs analysis done.

2). Analysis of results in the second stage of the ISM namely identifying the type of ISM to be constructed had determined the connection phrase and contextual phrase to be structured in the ISM. The findings show that the phrase appropriate to the context of the study is as follows:

The association/relationship/connecting phrase: has higher priority compared.

The contextual phrase: "For increasing the intake of nutritious fruits and vegetables among indigenous primary school pupils, the content ..."

The phrase concerned is selected as the procedure phrase of ISM because the researcher wants to identify the relationship from the perspective of importance of the content elements constructed from the context of development of the curriculum content model based on nutrititious fruits and vegetables. The connecting phrase was also agreed uponby the experts in the NGT session in stage 4 .

Table 1 gives the curriculum content elements for Garden Based Curriculum on Nutritious Fruits and Vegetables for Indigenous Primary Schools. 
Table 1. Curriculum Content Elements for Garden Based Curriculum on Nutritious Fruits and Vegetables for Indigenous Primary Schools.

\begin{tabular}{|c|c|c|}
\hline No. & Content Element & Explanation \\
\hline 1 & $\begin{array}{l}\text { The importance of food hygiene and safety and obtaining } \\
\text { health benefit from nutritious fruits and vegetables. }\end{array}$ & $\begin{array}{l}\text { Importance of food cleanliness including method of preparation and aspect of } \\
\text { preparation and managing food based on fruits and vegetables as well as the } \\
\text { importance of health from consuming fruits and vegetables from the perspective of } \\
\text { physical and cognitive development among indigenous children. }\end{array}$ \\
\hline 2 & $\begin{array}{l}\text { Planting of fruits and vegetables suited to the } \\
\text { sociocultural environment of the indigenous people. }\end{array}$ & $\begin{array}{l}\text { Encompasses the planting of suitable fruits and vegetables from the aspect of easy } \\
\text { accessibility and alignment with the culture and beliefs or taboos in consuming fruits } \\
\text { and vegetables in the indigenous people. }\end{array}$ \\
\hline 3 & $\begin{array}{l}\text { Method of planting and growing vegetables and fruits that } \\
\text { is effective and safe such as non-soil culture (hydroponic). }\end{array}$ & $\begin{array}{l}\text { The effective method of planting and way of propagating vegetables and fruits } \\
\text { namely a safe method that offers quick results. }\end{array}$ \\
\hline 4 & $\begin{array}{l}\text { Managing post harvest and preparing vegetables and } \\
\text { fruits. }\end{array}$ & $\begin{array}{l}\text { Encompassing the post harvest management namely after production of plants } \\
\text { immediately after harvesting, including freezing, cleaning, separating and packaging } \\
\text { of fruits and vegetables. }\end{array}$ \\
\hline
\end{tabular}

3). The findings of phase 3 unearthed 11 experts selected according to the criteria determined. Selection of the panel was made through referrals by other experts who had wide experience related to the context of the study. Findings from the selected panel included experts in indigenous studies, indigenous nutrition, curriculum design, agriculture and activists from the Semai indigenous community. The researcher had a role as facilitator in this research to manage the discussion session in the ISM.

4). The findings from the fourth stage are the most critical namely the development of elements of curriculum content that have been agreed upon and have received consensus from the panel of experts through the NGT session. Seven original elements were presented to the experts and analysis of the discussions found that several elements had to be discarded and revised in terms of sentence structure to shortlist the final elements from expert consensus. The following are the final elements for content of the curriculum based on garden of nutritious fruits and vegetables for indigenous primary schools with explanations:

5). The findings of the fifth stage are the process whereby software namely ISM carries out mathematical calculation using technology. Based on the questions according to the paired elements suggested by the ISM software administered by the facilitator, the expert panel had achieved consensus according to majority vote for each element presented. In this stage also the facilitator plays a role to explain the situation or in interpreting the meaning of the problem put forward by ISM.

6). The findings of this stage form the findings leading to decision on consensus of experts with the final presentation of digraph produced as computer output. The digraph that shapes the model is given in Figure 2.

\begin{tabular}{|l|l|}
\hline $\begin{array}{l}\text { 1. Importance of fruits and vegetables, food hygiene and } \\
\text { cleanliness }\end{array}$ & $\begin{array}{l}\text { 2. Growing of fruits and vegetables suited to the environment and } \\
\text { socioculture of indigenous people }\end{array}$ \\
$\begin{array}{l}\text { 3. The effective and safe method of planting and propagating } \\
\text { fruits and vegetables such as soil free culture }\end{array}$ & 4. Post harvest management and preparation of fruits and vegetables \\
\hline
\end{tabular}

Figure 2. Design of the Curriculum Content Model for Garden Based Curriculum on Nutritious Fruits and Vegetables for Indigenous Primary Schools.

7). The findings of the final stage namely discussion and amendment of structure show that the panel of experts have achieved consensus to retain without amendment the module design produced. Before decision is made for retaining the constructed model, the facilitator explains and interpretes the structure of relationship between the content elements developed. The panel of experts have confirmed the resulting model.

Based on Figure 2, it can be seen that the elements involved have a straightforward relationship where element 1 The importance of food hygiene and safety and obtaining health benefit from nutritious fruits and vegetables and 3 Effective and safe method of planting and growing vegetables and fruits that is such as non-soil culture (e.g., hydroponic) are, with both having four driving powers and two powers of dependence because this element has influence on their own selves and elements 1 dan 3 and also other elements namely element 2 Planting fruits and vegetables suited to thesociocultural environment of the indigenous people and element 4 Post harvest management and preparation of fruits and vegetables. This can be interpreted in the teaching and learning process of indigenous children in school such that the content 1 and 3 must supersede contents 2 and 4 during implementation. Meanwhile element 2 dan 4 have two driving powers and four dependence powers; both these elements are influenced themselves and also by elements 1 and 3 .

\section{Discussion}

To answer the first research question, elements of the curriculum content model based on nutritious fruits and vegetables for indigenous primary schools have resulted from the views and discussions among experts through the NGT 
namely the fourth stage in the ISM procedure. The findings of analysis listed 4 elements of the curriculum content that needed to be inserted into the curriculum content model based on nutritious fruits and vegetables for the indigenous primary schools as given inTable 1 .

Based on the findings for research question 1 , the most important element of curriculum content is element 1 namely the importance of food hygiene and health from fruits and vegetables. This is in line with the study by Benton and Ross, involving development of a health education program for indigenous people; aimed at educating indigenous children regarding excellent health, the study emphasized program content, with elements of cleanliness and health including personal hygiene and eating fruits before main meals and eating vegetables with meals. Meanwhile, the content element at the lowest level is Post harvest management and preparation of fruits and vegetables. In line with several studies [57-59] among the program activities in the school garden used as part of the curriculum content based on garden are activities related to planting, managing the harvest, as well as preparation of harvested fruits and vegetables whether for sale or used in other dishes.

In answering research question 2 namely on the design of garden based curriculum content model for nutritious fruits and vegetables for indigenous primary schools, findings from anal; ysis of expert consensus show the model design as in Figure 1. The findings show that element 3 had a level of priority similar to element 1 because it was aligned with previous studies clarifying that skill in planting approach forms a main element in a program of garden based curriculum as in agreement with Graham and Heim. These studies underscore other findings where develpoping educational programs on diet guided by social cognitive theory is through planting that gives opportunity to improve knowledge and skills related to healthy diet through fruits and vegetables.

Similarly with the design of the model that showed element 2 Planting fruits and vegetables suited to the sociocultural environment of the indigenous people and element 4 Post harvest management and preparation of fruits and vegetables both have a priority level that are the same and the curriculum content element for the context of this study must be carried out after element 1 and 3 because element 2 and 4 had a high level of dependence on element 1 dan 3. This finding is closely related to other findings [60], closely relating the environment and cultural factor to the performance of indigenous children. The life of the indigenous people (Orang Asli) is very closely tied to their environment namely the forest that is their main source of livelihood; hence the content element relating the sociocultural aspect suited to them can enhance their enthusiasm given the existing knowledge and sociocultul understanding of these indigenous children. Mohd Nazri also emphasized the importance of indigenous values and culture in developing alternative forms of education.

\section{Conclusion}

Based on findings of this study, it can be concluded that four elements identified as influencing the development of the curriculum content model based on nutritious fruits and vegetables for Semai Orang Asli primary schools are: (1)The importance of cleanliness in health and diet from nutritious fruits and vegetables; (2) Planting fruits and vegetables suitable for the socio-cultural environment of the Orang Asli; (3) Effective and safe approach to planting and propagating fruits and vegetables such as non-soil culture; (4) Post harvest management and preparation of fruits and vegetables. Development of a curriculum content model based on garden of nutritious fruits and vegetables constructed shows the relationship of importance between elements. In addressing the issue of consumption of nutritious fruits and vegetables, the curriculum content model being built can help researchers and administrators in directing them to their major objective or goal namely in increasing the intake of nutritious fruits and vegetables among the Semai Orang Asli children. The importance of developing a curriculum content model is also in line with the importance of developing curriculum objectives, teaching and learning method as well as evaluation and measurement of the Garden Based Curriculum on Nutritious Fruits and Vegetables for Indigenous Primary Schools. Hence for future research it is suggested that model of curriculum objectives, the teaching and learning approaches as well as the evaluation model and measurement for achieving the objectives of a garden based curriculum on fruits and vegetables be developed.

\section{References}

[1] Marzuki, M., Mapjabil, J., \& Zainol, R. M. Mengupas keciciran pelajar Orang Asli Malaysia: Suatu tinjauan ke dalam isu aksesibiliti sekolah. Malaysian Journal of Society and Space, 10(2), 189 - 198, 2014.

[2] Ahmed, A., Al-Mekhlafi, H. M., Azam, M. N., Ithoi, I., AlAdhroey, A. H., Abdulsalam, A. M., \& Surin, J. Soiltransmitted helminthiasis: A critical but neglected factor influencing school participation of Aboriginal children in rural Malaysia. Parasitology, 139(06), 802-808, 2012.

[3] Abu Talib Bon, Abdullah, M. A., Othman, H., Mohd Salleh, B., Mustafa, S., Hashim, R., \& Sulaiman, A. Kenali Kami Masyarakat Orang Asli di Malaysia. Penerbit KUiTTHO, 2003.

[4] Hanafi, W. A. W., Ahmad, S., \& Ali, N. Faktor budaya dan persekitaran dalam prestasi pendidikan anak Orang Asli Malayia: Kajian kes di Kelantan. Geografia: Malaysian Journal of Society and Space, 10(5), 107-122, 2014.

[5] Khor G. K., \& Zalilah, M. S. The ecology of health and nutrition of Orang Asli (Indigenous people) women and children in Peninsular Malaysia. Tribes and Tribals, 2, 66-77, 2008 .

[6] Talib, J., \& Muslim, N. Bagaimana kanak-kanak Orang Asli gagal di sekolah? MALIM: Jurnal Pengajian Umum Asia Tenggara, 8, 51-76., 2007. 
[7] Mohd Nazri Abdul Rahman. Pembangunan model Homeschooling berasaskan nilai dan amalan masyarakat bagi kanak-kanak Orang Asli. (Tesis PhD, Universiti Malaya, Kuala Lumpur), 2014.

[8] Haslinah Abdullah. Faktor isi rumah, status pemakanan dan kesihatan yang mempengaruhi keupayaan kognitif am kanakkanak Orang Asli. (Kertas Ilmiah tidak diterbitkan). Universiti Putra Malaysia, Serdang, 2009.

[9] Al-Mekhlafi, H. M., Surin, J., Sallam, A. A., Abdullah, A. W., \& Mahdy, M. A. Giardiasis and poor vitamin A status among aboriginal school children in rural Malaysia. The American Journal of Tropical Medicine and Hygiene, 83(3), 523-527, 2010.

[10] Mohamad Johdi Salleh \& Abdul Razak Ahmad. Kesedaran pendidikan dalam kalangan masyarakat Orang Asli. In Masyarakat Orang Asli: Perspektifpendidikan dan sosiobudaya (pp. 47-58). Bangi: Penerbit Universiti Kebangsaan Malaysia, 2009.

[11] Khor G. K., \& Zalilah, M. S. (2008). The ecology of health and nutrition of Orang Asli (Indigenous people) women and children in Peninsular Malaysia. Tribes and Tribals, 2, 66-77.

[12] Benton, D. The influence of dietary status on the cognitive performance of children. Molecular Nutrition \& Food Research, 54(4), 457-470, 2010.

[13] Fanjiang, G., \& Kleinman, R. E. Nutrition and performance in children. Current Opinion in Clinical Nutrition \& Metabolic Care, 10(3), 342-347, 2007.

[14] Ross, A. Nutrition and its effects on academic performance: How can our schools improve? Retrieved from https://www.nmu.edu/sites/DrupalEducation/files/UserFiles/Fi les/PreDrupal/SiteSections/Students/GradPapers/Projects/Ross _Amy_MP.pdf, 2010.

[15] Carroll C. Better Academic Performance: Is Nutrition the Missing Link. Today's Dietitian, 16(10), p. 64. Retrieved from http://www.todaysdietitian.com/newarchives/100614p64.shtml , 2014.

[16] DeMarco, L. W. The factors affecting elementary school teachers' integration of school gardening into the curriculum. $(\mathrm{PhD}$ thesis, Virginia Polytechnic and State University, Blacksburg, VA), 1997.

[17] Lineberger, S. E., \& Zajicek, J. M. School gardens: can a hands-on teaching tool affect students' attitudes and behaviors regarding fruit and vegetables? HortTechnology, 10(3), 593$597,2000$.

[18] Martin, S. C. The influence of outdoor schoolyard experiences on students' environmental knowledge, attitudes, behaviors, and comfort levels. Journal of Elementary Science Education, 15(2), 51-63, 2003.

[19] Thorp, L., \& Townsend, C. Agricultural education in an elementary school: An ethnographic study of a school garden. In Proceedings of the 28th Annual National Agricultural Education Research Conference in New Orleans, LA (pp. 347360), 2001.

[20] JHPIEGO. Nutrition core competencies for health cadres and undergraduate nutritionists in Ethiopia. Retrieved from $\mathrm{http} / / /$ reprolineplus.org/system/files/resources/Nutrition_CC_ Health.pdf, 2012.
[21] Kementerian Pendidikan Malaysia. Pelan Pembangunan Pendidikan Malaysia 2013-2025. Kuala Lumpur: Pusat Perkembangan Kurikulum Kementerian Pendidikan Malaysia, 2012.

[22] Md Nor, S., Roslan, S., Mohamed, A., Hassan, A., Hj, K., Ali, M. A. M., \& Manaf, J. A. Dropout prevention initiatives for Malaysian indigenous Orang Asli children. International Journal on School Disaffection, 8(1), 42-56, 2011.

[23] Ramlah Abdul Rahman. Projek Rintis Kurikulum Bersepadu Sekolah Murid Orang Asli Dan Penan (Kap.) Diambil dari http://jpmipgmtaa.webs.com/Aktiviti_Jabatan/Laporan\%20K AP\%202009.pdf, 2007.

[24] Marzuki, M., Mapjabil, J., \& Zainol, R. M. Mengupas keciciran pelajar Orang Asli Malaysia: Suatu tinjauan ke dalam isu aksesibiliti sekolah. Malaysian Journal of Society and Space, 10(2), 189 - 198, 2014.

[25] Ahmed, A., Al-Mekhlafi, H. M., Azam, M. N., Ithoi, I., AlAdhroey, A. H., Abdulsalam, A. M., \& Surin, J. Soiltransmitted helminthiasis: A critical but neglected factor influencing school participation of Aboriginal children in rural Malaysia. Parasitology, 139(06), 802-808, 2012.

[26] Kamarulzaman, K., \& Osman, J. Educational policy and opportunities of Orang Asli: A study on indigenous people in Malaysia. The Journal of Human Resource and Adult Learning, 4(1), 86-97, 2008.

[27] Thanabalan, T. V., Siraj, S., \& Alias, N. Development of a responsive literacy pedagogy incorporating technology for the indigenous learners in Malaysia. Turkish Online Journal of Educational Technology-TOJET, 13(2), 44-53, 2014.

[28] Wahab, N. A., Ahmad, A. R., Jelas, Z. M., Rahman, N. A., \& Halim, L. The role and perspectives of administrators in the schools of Orang Asli Students: A case study in the State of Pahang. International Proceedings of Economics Development and Research, 78, 27, 2014.

[29] Mohamad Johdi Salleh, Norul Khairiah Idris, Nur Awanis Abd Aziz, Nurul Huda Yusuf \& Siti Aisyah Hashim. Kajian terhadap kesedaran pendidikan dalam kalangan masyarakat orang asli. In Persidangan Kebangsaan Pendidikan Luar Bandar 2009, 3 - 5 February 2009, University Malaysia of Sabah, 2009.

[30] Nettleton S. Memberi galakan awal kepada generasi 'Orang Asli' seterusnya di Malaysia. Diambil dari http://www.unicef.org/malaysia/msl/reallives_6687.html

[31] Grantham-McGregor, S., \& Ani, C. A review of studies on the effect of iron deficiency on cognitive development in chil dren. The Journal of Nutrition, 131(2), 2001.

[32] Rosnon, M. R. Discourse of Indigenous Education Policy: The Malaysian Case. International Journal for Innovation Education and Research, 3(10), 2015.

[33] Asmara Alias, Jamilah Hamid, Harnani Mat Zin, Saira Banu Omar Khan, \& Norhasbiah Ubaidullah Development of ICTL module-based on suitable teaching methodology for Orang Asli (ICTL-TeMfOA): The preliminary study of suitable teaching strategy. In 2011 7th International Conference on Information Technology in Asia, 2011.

[34] Aniza Mohd Said, Norlidah Alias, \& Saedah Siraj. Keperluan model kurikulum berasaskan intelektualisme perubatan herba masa depan. Jurnal Kurikulum dan Pengajaran Asia Pasifik, 3(1), 2015. 
[35] Vanitha, T. Development of a digital story pedagogical module to facilitae reading among indigenous primary school stu dents. (Unpublished PhD thesis, University of Malaya, Kuala Lumpur), 2011.

[36] Klemmer, C. D., Waliczek, T. M., \& Zajicek, J. M. Growing minds: The effect of a school gardening program on the science achievement of elementary students. HortTechnology, 15(3), 448-452, 2005.

[37] Myers, B. E., \& Washburn, S. G. Integrating science in the agriculture curriculum: Agriculture teachers' perceptions of the opportunities, barriers, and impact on student enrollment. Journal of Agricultural Education, 49(2), 27-37, 2008.

[38] Pigg, A., Waliczek, T., \& Zajicek, J. Effects of a gardening program on the academic progress of third, fourth, and fifth grade math and science students. HortTechnology, 16(2), 262, 2006.

[39] Skelly, S. M., \& Bradley, J. C. The growing phenomenon of school gardens: Measuring their variation and their affect on students' sense of responsibility and attitudes toward science and the environment. Applied Environmental Education and Communication, 6(1), 97-104, 2007.

[40] Smith, L. L., \& Mostenbocker, C. E. Impact of hands-on science through school gardening in Louisiana public ele mentary schools. HortTechnology, 15, 439-443, 2005.

[41] Waliczek, T. M., Logan, P., \& Zajicek, J. M. Exploring the impact of outdoor environmental activities on children using a qualitative text data analysis system. HortTechnology, 13(4), 684-688, 2003.

[42] Ratcliffe, M. M. Garden-based Education in School Settings: The Effects on Children's vegetable consumption, vegetable preferences and ecoliteracy. (Dissertation, Tufts University's Friedman School of Nutrition Science and Policy), 2007.

[43] Oxenham, E., \& King, A. D. School gardens as a strategy for increasing fruit and vegetable consumption. Journal of Child Nutrition \& Management, 34(1), 2010.

[44] Parker, S. P., Siewe, Y. J., \& Denney, B. A. After-school gardening improves children's reported vegetable intake and physical activity. Journal Nutrition Education Behavior, 38, 201-202, 2006.

[45] Heim, S., Stang, J., \& Ireland, M. A garden pilot project enhances fruit and vegetable consumption among children. Journal of the American Dietetic Association, 109(7), 12201226, 2009.

[46] Mian, L. H., \& Leng, C. H. Nutritional status and reproductive health of Orang Asli women in two villages in Kuantan, Pahang. Malaysian Journal of Nutrition, 4, 31-54, 1998.

[47] Morris, J. L., \& Zidenberg-Cherr, S. Garden-enhanced nutrition curriculum improves fourth-grade school children's knowledge of nutrition and preferences for some vegetables. Journal of the American Dietetic Association, 102(1), 91-93, 2002.

[48] Parmer, S. M., Salisbury-Glennon, J., Shannon, D., \& Struempler, B. School gardens: an experiential learning approach for a nutrition education program to increase fruit and vegetable knowledge, preference, and consumption among second-grade students. Journal of Nutrition Education and Behavior, 41(3), 212-217, 2009.

[49] Robinson-O'Brien, R., Story, M., \& Heim, S. Impact of ga rden-based youthnutrition intervention programs: a review. Journal of the American DieteticAssociation, 109(2), 273-280, 2009.

[50] Wisconsin Nutrition, Physical Activity \& Obesity Program. Got Veggies? Garden-Based Nutrition Education Curriculum. University of Wisconsin-Madison School of Medicine and Public Health. Retrieved from https://www.dhs.wisconsin.gov/publications/p0/p00228.pdf, 2009.

[51] Mohd Nazri Abdul Rahman, Norlidah Alias, Saedah Siraj, \& Dorothy Dewitt. Aplikasi ISM dalam penerbitan Buku Teks Sekolah Menengah di Malaysia. Seminar Penyelidikan Zon Sabah, INTAN, Kota Kinabalu, 1-3 Okt 2012.

[52] Abdullah, M. R. T. L., Siraj, S., Hussin, Z., Leng, C. H., \& Yean, L. L. Interpretive structural activity-based mlearning implementation model of undergraduate English language learning: A theoretical mapping. Procedia-Social and Behavioral Sciences, 176, 299-306, 2015.

[53] Sahney, S., Banwet, D. K., \& Karunes, S. An integrated framework for quality in education: Application of quality function deployment, interpretive structural modelling and path analysis. Total Quality Management \& Business Excellence, 17(2), 265-285, 2006.

[54] Gorvett, R., FRM, A., \& Liu, N. Interpretive structural modeling of interactive risks. Enterprise Risk Management Symposium Society of Actuaries, 8, 23-26, 2006.

[55] Kanungo, S. \& Jain, V. Using Interpretive Structural Modeling to uncover shared mental models in IS research. In Proceedings of the European Conference on Information Systems (ECIS), June 8-10, Verona, Italy, Paper 192, 2009.

[56] Janes, F. R. Interpretive structural modeling: A methodology for structuring complex issues. Transactions of the Institute of Measurement and Control, 10(3), 145154, 1988.

[57] Mc Aleese, J. D., \& Rankin, L. L. Garden-based nutrition education affects fruit and vegetable consumption in sixthgrade adolescents. Journal of the American Dietetic Association, 107(4), 662-665, 2007.

[58] Morris, J. L., \& Zidenberg-Cherr, S. Garden-enhanced nutrition curriculum improves fourth-grade school children's knowledge of nutrition and preferences for some vegetables. Journal of the American Dietetic Association, 102(1), 91-93, 2002.

[59] Robinson-O'Brien, R., Story, M., \& Heim, S. Impact of garden-based youthnutrition intervention programs: a review. Journal of the American DieteticAssociation, 109(2), 273-280, 2009.

[60] Graham, H., Beall, D. L., Lussier, M., McLaughlin, P., \& Zidenberg-Cherr, S. Use of school gardens in academic instruction. Journal of Nutrition Education and Behavior, 37(3), 147-151, 2005. 